\title{
HOW ARBUSCULAR MYCORRHIZAL FUNGI INFLUENCE THE DEFENSE SYSTEM OF SUNFLOWER DURING DIFFERENT ABIOTIC STRESSES
}

\author{
Zoltán Mayer, * Nguyen Hong Duc, Zita Sasvári and Katalin Posta \\ Szent István University, Institute of Genetics, Microbiology and Biotechnology \\ Páter Károly 1., Gödöllö, Hungary
}

(Received: February 9, 2017; accepted: July 13, 2017)

\begin{abstract}
The association between terrestrial plants and arbuscular mycorrhizal (AM) fungi is one of the most common and widespread mutualistic plant-fungi interaction. AM fungi are of beneficial effects on the water and nutrient uptake of plants and increase plant defense mechanisms to alleviate different stresses. The aim of this study was to determine the level of polyphenol oxidase (PPO), guaiacol peroxidase (POX) and glutathione S-transferase (GST) enzyme activities and to track the expression of glutathione S-transferase (GST) gene in plant-arbuscular mycorrhizal system under temperature- and mechanical stress conditions. Our results suggest that induced tolerance of mycorrhizal sunflower to high temperature may be attributed to the induction of GST, POX and PPO enzyme activities as well as to the elevated expression of GST. However, the degree of tolerance of the plant is significantly influenced by the age which is probably justified by the energy considerations.
\end{abstract}

Keywords: Enzyme activity - GST gene-expression - arbuscular mycorrhizal fungi - stress - plantdefense system

\section{INTRODUCTION}

Plants are often faced to the combined effect of various biotic and abiotic stresses. Abiotic stresses such as drought, chilling are often the major limiting factors for crop productivity. Under stress conditions reactive oxygen species (ROS) are generated in plants which are highly reactive and toxic. Plants can detoxify these oxidative molecules through elevating antioxidant activity of ROS-scavenging enzymes such as catalase, superoxide dismutase and peroxidase and glutathione S-transferase $[13,15$, 20, 26-28, 30], moreover enhancing non-enzymatic antioxidants [e.g., ascorbate, glutathione and tocopherols) in plants [11, 29].

Successful establishment, survival and productivity of a crop mainly depend on its adaptation to environmental conditions. There are some options how plants tolerate the extreme unfavourable conditions. One of the possibilities is the inoculation of crop by arbuscular mycorrhizal fungi. The association between terrestrial plants and

\footnotetext{
*Corresponding author; e-mail address: Mayer.Zoltan@mkk.szie.hu
} 
arbuscular mycorrhizal (AM) fungi is one of the most widespread forms of mutual plant-fungal interaction in natural and agricultural systems. This symbiotic relationship has evolved more than 400 million years ago giving possibility for plants to previal on Earth [31, 46, 47, 50]. The beneficial effects of AM are well known, including enhanced uptake of water and - mostly phosphorus - nutrient, in addition to reduction of weeds and protection against pathogens $[1,4,45,48]$. Several studies suggest that AM symbiosis can help plants to alleviate various biotic and abiotic stresses. For instance, mycorrhiza-induced resistance (MIR) provides systemic protection against a wide range of plant pathogens $[10,19,35,36]$. Instead of constitutive activation of plant defense system, MIR is associated with priming for an efficient activation of JA-dependent system [9, 35]. Moreover, some works show clearly that the amelioration of stress resistance by AM symbiosis is often related to the enhancement of antioxidant levels or activities in mycorrhizal plants [2]. The regulations of these mechanisms are not well understood and only a few investigations have been carried out at early stages of plants concerning low level of mycorrhizal colonization. Therefore, the main objectives of current research were to study how the arbuscular mycorrhizal inoculation influence the activities of some plant defense enzymes together with the expression of GST gene under non-stress, mechanical and temperature stress conditions at early stage of plants.

\section{MATERIAL AND METHODS}

\section{Plant material and growth conditions}

Seeds of sunflower (Helianthus annuus L.) were surface sterilized by immersion into $70 \%$ ethanol for $5 \mathrm{~min}$, rinsed four times with distilled water and placed on wet filter paper in Petri dishes at $28{ }^{\circ} \mathrm{C}$ for germination. After 3 days, the germinated seeds were transplanted into plastic pots containing $0.88 \mathrm{~kg}$ sterilized soil substrate (organic manure, soil and decomposed straw $=1: 2: 1)$. Half of the pots were inoculated with $15 \mathrm{~g}$ of a commercial mycorrhizal product, Symbivit ${ }^{\circledR}$ (mixture of Rhizophagus irregularis, Funneliformis mosseae, Claroideoglomus etunicatum, Claroideoglomus claroideum, G. microaggregatum, Funneliformis geosporum) produced by Symbiom Ltd. (Lanskroun, Czech Republic; www.symbiom.cz) and the rest was used for not AM-inoculated treatments. The seedlings of both treatments were grown in growth chamber under controlled conditions with 16 hours day length and at temperature of $24{ }^{\circ} \mathrm{C} \pm 0.5^{\circ} \mathrm{C}$. The moisture of substrate was $60 \%$.

Healthy 9,15 and 42 days-old seedlings (mycorrhizal and non-mycorrhizal plants) were selected and exposed to different stress conditions, including three stress treatments. Plants were exposed to $38{ }^{\circ} \mathrm{C}$ for $24 \mathrm{~h}$ (High Temperature stress, HT) or were incubated for $24 \mathrm{~h}$ at $4{ }^{\circ} \mathrm{C}$ (Chilling stress, LT). Moreover, hypocotyls were injured in sunflower seedlings by nicking them with a striped-tip forceps, after $24 \mathrm{~h}$ the leaves were collected and analyzed (Mechanical Wounding stress, MW). All treatments (HT, LT, MW and non-stressed control) were replicated five times. 


\section{RNA isolation and cDNA synthesis}

To detect the expression profiles of glutathione S-transferase gene, total RNA was extracted from 15- and 42-day-old sunflower leaves using Vantage Total RNA Purification Kit (Origene, USA) according to the manufacturer's instructions, followed by DNase I (Fermentas) digestion to remove residual genomic DNA contamination. For qRT-PCR analysis, first-strand cDNA was synthesized from varieties of all treatments using First-strand cDNA Synthesis for Quantitative RT-PCR kit (Origene, USA). QRT-PCR was performed on Stratagene Mx3000P QPCR System (Agilent Technologies).

Each reaction was performed in a final volume of $25 \mu$ containing $12.5 \mu \mathrm{l} \mathrm{SYBR}$ Green Master Mix reagent (Applied Biosystems), $1 \mu$ of diluted cDNA sample (equal concentration in final volume, $4 \mathrm{ng} / \mu \mathrm{l}), 70 \mathrm{nM}$ gene-specific primers and $8 \mu \mathrm{l}$ nuclease-free water. The gene-specific primers GST-f (5'-GAGAAGGCTCAGGCTCGATT-3') and GST-r (5'-GCAACAGCTTGCTTCTCTCC-3') were designed according to Radwan et al. [37]. The thermal cycle was used as follows: $95^{\circ} \mathrm{C}$ for $15 \mathrm{~min}$, followed by 40 cycles at $95{ }^{\circ} \mathrm{C}$ for $15 \mathrm{sec}, 57^{\circ} \mathrm{C}$ for $30 \mathrm{sec}$ and $72{ }^{\circ} \mathrm{C}$ for $16 \mathrm{sec}$, finally 1 cycle at $95{ }^{\circ} \mathrm{C} 60 \mathrm{sec}, 57^{\circ} \mathrm{C} 30 \mathrm{sec}$ and $95^{\circ} \mathrm{C} 30 \mathrm{sec}$. The real-time PCR experiment was carried out at least three times under identical conditions. Amplification of actin gene was used as an internal reference. The gene expression of glutathione S-transferase was calculated using the $2^{-\Delta \Delta \mathrm{CT}}$ method.

\section{Enzyme assays}

Half gram of fresh leaf and hypocotyl segment from 9-, 15- and 42-day-old sunflower leaves was homogenized in Tris- $\mathrm{HCl}(3 \mathrm{ml} ; 50 \mathrm{mM}$; $\mathrm{pH} 7.8)$; polyvinylpyrrolidone-K $25(7.5 \%(\mathrm{w} / \mathrm{v})$ and EDTA-Na $2(1 \mathrm{mM})$ buffer. The homogenate was centrifuged at $10,000 \mathrm{~g}$ for $20 \mathrm{~min}$ at $4{ }^{\circ} \mathrm{C}$ and the supernatant was used for further measurements. The level of guaiacol peroxidase activity was tested according to Rathmell and Sequera [39]. Sodium phosphate buffer $(2.2 \mathrm{ml} ; 0.1 \mathrm{M}$; pH 6.0), guaiacol (100 $\mu \mathrm{l} ; 50 \mathrm{mM})$ and $\mathrm{H}_{2} \mathrm{O}_{2}(100 \mu \mathrm{l} ; 12 \mathrm{mM})$ were added to the plant extract $(10 \mu \mathrm{l})$. The absorbance was recorded at $436 \mathrm{~nm}$ using Nanophotometer 2210 (Implen, Germany). The activity of polyphenol oxidase in 9,15 and 42 days-old sunflower was determined by adding $200 \mu \mathrm{l}$ of plant extract to sodium phosphate buffer $(2,2 \mathrm{ml} ; 0.1 \mathrm{M}$; pH 6.0), EDTA $\mathrm{Na}_{2}(1 \mathrm{mM})$ and catechol $(20 \mathrm{mM})$ as described by Fehrmann and Dimond [16]. The polyphenol oxidase activity was measured by the increase in the absorbance at $400 \mathrm{~nm}$ using Nanophotometer 2210 (Implen, Germany). Changes of absorbance per protein concentration per unit time were estimated. Glutathione S-transferase enzyme activity in 15- and 42-day-old sunflower plants was assayed according to the method of Habig et al. (1974) [18]. The absorbance was followed at $340 \mathrm{~nm}$ (Nanophotometer 2210, Implen, Germany) using $0.1 \mathrm{ml}$ GSH (30 mM), 0.1 $\mathrm{ml} \mathrm{CDNB}(30 \mathrm{mM})$ and $2.7 \mathrm{ml}(100 \mathrm{mM}, \mathrm{pH}$ 6.5) phosphate buffer were added to 0.1 $\mathrm{ml}$ plant extract. Bradford reagent was used to determine the concentration of total 
soluble protein in plant extract solutions using bovine serum albumin as a standard [5]. Statistics were performed with R Statistical Sofwer 3.3.1 (R Development Core Team 2011). Differences between treatments were determined by one-way analysis of variance (ANOVA).

\section{Assessment of mycorrhizal colonization of AMF}

Five plants both from mycorrhizal and non-mycorrhizal treatments were used for estimating root colonization. Approximately, $500 \mathrm{mg}$ of fine roots from each plant were transferred to separate tubes and were subjected to the staining technique of Vierheilig et al. [51]. Internal fungal structures (hypae, arbuscules, vesicules) were examined under a stereomicroscope at $\times 100$ magnification and the percentage of root length colonized calculated using the gridline intersect method [17].

\section{RESULTS}

During the 42 days of growth, no growth responses could be observed between mycorrhizal and non-mycorrhizal treatments (data not shown). No colonization was recognized in not-inoculated control plants and the highest level of mycorrhizal colo-

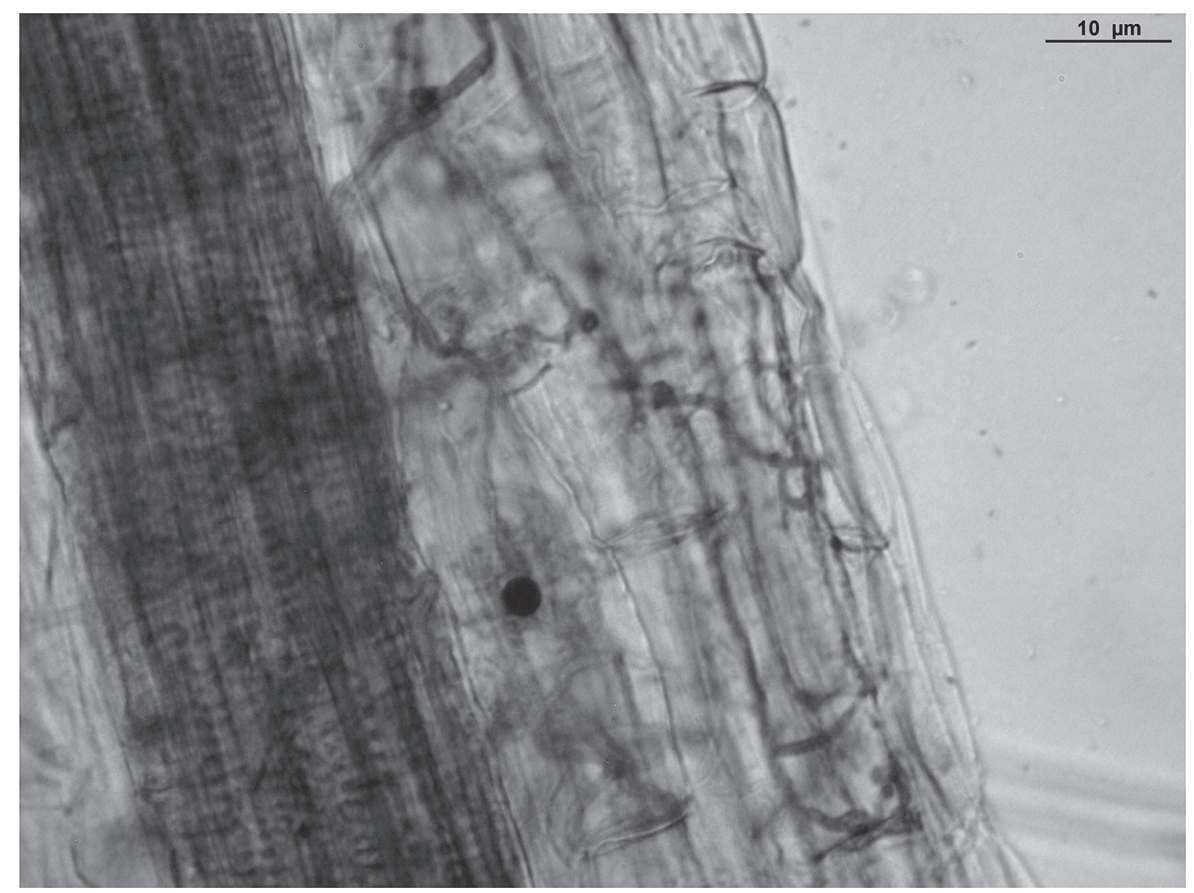

Fig. 1. Internal hyphae and arbusculum in 42-day-old plant 
nization (58\%) was reached by 6 weeks. We did not find any differences in mycorrhizal colonization among the plants used for the same stress situations (data not shown).

Nine days after mycorrhizal inoculation, at early stage of symbioses, appressorium and external hyphae together with germinated spores of AMF were only detected, however, internal hyphae (Fig. 1) and arbusculum were recorded after 42 days of growth. In general, mycorrhizal inoculation caused changes in all measured enzymes activities but significant differences detected only in POX activity. During control condition (without stress) the mycorrhizal plants showed a 11.5 times higher guaiacol-peroxidase activity than non-mycorrhizal one (AM-) (Fig. 2b). Mechanical wounding occurred enhancing activities of both POX and PPO in not inoculated plants, however mycorrhizal plants showed significantly lower enzymes activities compared to non-mycorrhizal ones (Fig. 2a, 2b).

Fifteen days after inoculation no significant differences could be detected regarding all measured enzyme activities (PPO, POX, GST) between mycorrhizal and nonmycorrhizal plants. Various stresses caused different effects. Chilling increased the $\mathrm{PPO}$ in both $\mathrm{AM}+$ and $\mathrm{AM}-$ treatments (Fig. 2c). The short high temperature stress had significant influence only on GST activity, increasing the glutathione S-transferase level both in mycorrhizal and non mycorrhizal plants compared with nonstressed condition (Fig. 2g). Mechanical wounding increased the activity of POX enzyme, showing significant level only in non-mycorrhizal plants compared with control condition (Fig. 2d).

Mycorrhizal inoculation did not cause any differences in measured enzyme activities during control, non-stressed condition after 42 days of growth. However, high temperature increased significantly all tested enzyme activities (PPO, POX, GST) in both mycorrhizal and non-mycorrhizal plants. Moreover, differences in enzyme levels between inoculated and non-inoculated plants were also detected. Mycorrhizal plants showed 3.58, 1.65 and 1.6 times higher activity of PPO, POX and GST, respectively, after short high temperature stress compared with non-inoculated ones (Fig. 2e, 2f, 2h). Mechanical wounding caused a similar effect, however it was detected only in POX activity (Fig. 2f). We did not find any significant difference between mycorrhizal and non-mycorrhizal plants in PPO, but mechanical stress caused increased enzyme activity in plants compared with control ones. Chilling stress enhanced PPO activities in both AM+ and AM- treatments compared with nonstressed condition, however, no significant difference was found between inoculation treatments (Fig. 2e).

Fig. 2. Polyphenol oxidase, guaiacol peroxidase and glutathione S-transferase enzyme activity. (a) PPO activity in 9-day-old plant; (b) POX activity in 9-day-old plant; (c) PPO activity in 15-day-old plant; (d) POX activity in 15-day-old plant; (e) PPO activity in 42-day-old plant; (f) POX activity in 42-day-old plant; (g) GST activity in 15-day-old plant; (h) GST activity in 42-day-old plant; C - Control; LT - Low Temperature stress; HT - High Temperature stress; MW - Mechanical Wounding stress; Light grey represents the non-inoculated plants; Dark grey - represents the inoculated plants with mycorrhizal fungi. Different letters represent significantly different $(\mathrm{P}<0.05)$ values 

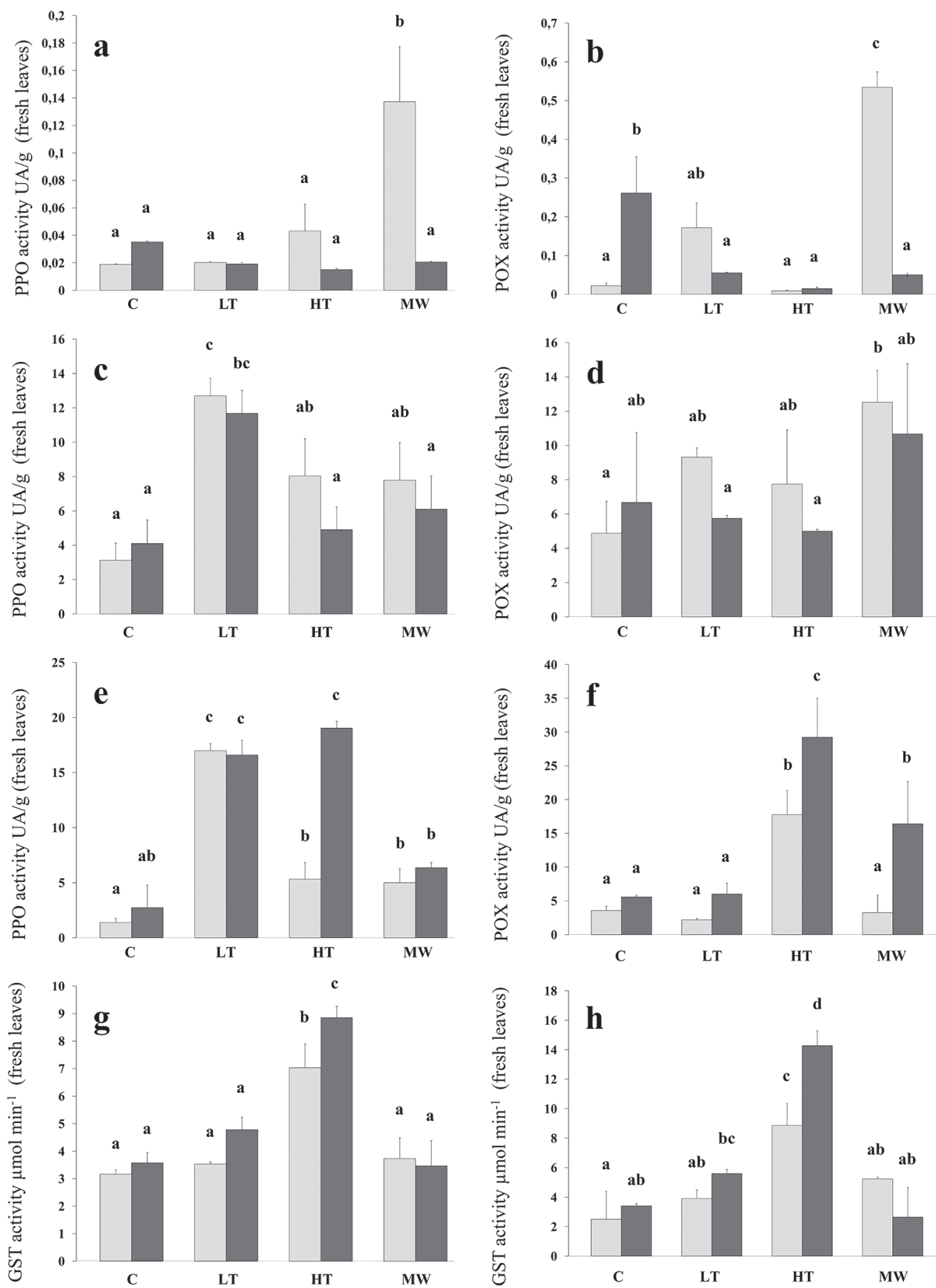
Mycorrhizal inoculation increased GST gene expression both after 15 and 42 days of growth. From tested stresses the high temperature caused the most significant differences in glutathione S-transferase gene expression between mycorrhizal and nonmycorrhizal treatments at both sampling times. However, the two-fold higher gene expression in $\mathrm{AM}+$ plants measured after 15 days of inoculation decreased to a 1.4fold level at 42 days (Fig. 3a, 3b). In general, stress condition enhanced GST gene expression compared to the control one; only mechanical wounding had negative effect on expression level of mycorrhizal plant.
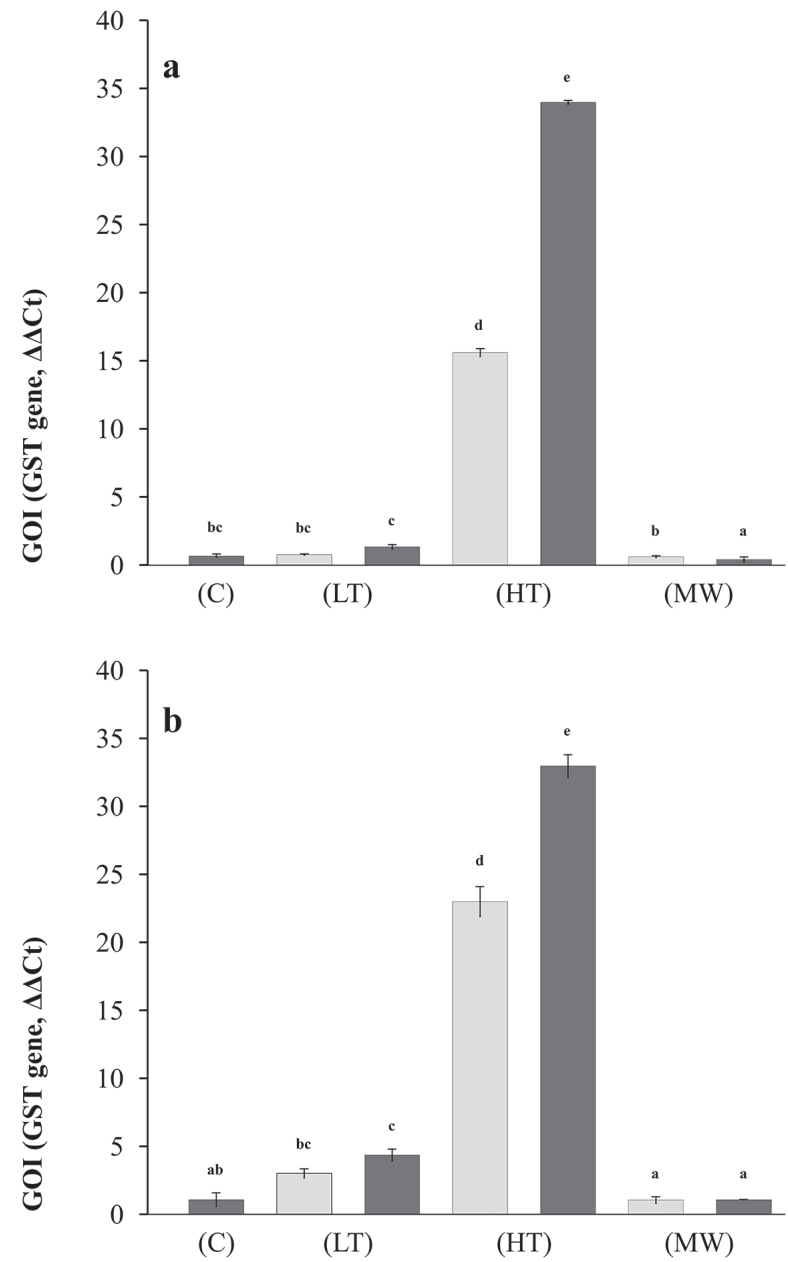

Fig. 3. Glutathione S-transferase gene expression. (a) GST gene expression in 15-day-old plant; (b) GST gene expression in 42-day-old plant; C - Control, inoculated with mycorrhizal fungi; LT - Low Temperature stress; HT - High Temperature stress; MW - Mechanical Wounding stress; Light grey represents the non-inoculated plants; Dark grey - represents the inoculated plants with mycorrhizal fungi. Different letters represent significantly different $(\mathrm{P}<0.05)$ values 


\section{DISCUSSION}

Pre-symbiotic stage of sunflower-mycorrhizal fungi interaction seems similar to pathogen attack (against plant) restarting defense system of the plant. One of the earliest responses of plants to different stresses, involving AMF colonization, is the rapid accumulation of reactive oxygen species (ROS). ROS are not only harmful to the plant cell but also to mycorrhizal fungi which could be one reason for higher POX activities found in mycorrhizal plants than in non mycorrhizal plants under nonstressed conditions. It is in agreement with the studies of Spanu and Bonfante-Fasolo [3] finding transient and weak increments of POX activity at early colonization stages of the AM symbiosis by Allium roots. Increased peroxidase activity in plants was evoked not only by mycorrhiza, but also by different abiotic stresses [33, 38, 53]. This enzyme plays a role in producing of the monomers, dimers and phenoxy-free radicals as well and regulating the detrimental accumulation of hydrogen peroxide $\left(\mathrm{H}_{2} \mathrm{O}_{2}\right)$. Interestingly, neither high nor low temperatures caused any changes in this enzyme activity but only mechanical wounding as abiotic stress has significant effect on plant peroxidase after 9 days of growth. While decreased activity of POX in mycorrhizal plants was found compared to control ones, an opposite tendency was recognised in non-mycorrhizal plants under mechanical wounding and low temperature stress. At early stage of plant, mycorrhiza often seems to parasites, because the energy from plant photosynthesis does not cover the growth of mycorrhizal fungi together with plant requirement. It could after be one reason for lower enzyme activity of mycorrhizal plant than non-mycorrhizal one. Having bigger leaf surface, the plant has more energy for covering both the production of enzymes and the growth of fungi as detected during high temperature stress caused 42 days of growth compared to non-inoculated ones. Several authors [21, 32, 36] have reported various results (induction or suppression) of these enzymes during AM colonization indicating that the enzymes are somehow linked with the AM symbiotic process. Functional differences in interaction between AMF genera, species, even among strains within the same species have also been recognized [41-43]. Our result is in agreement with the work of Rodríguez et al. [40] who described in tomato roots that alterations of the antioxidant enzyme activities are not general characteristics of the colonization process by arbuscular mycorrhizal fungi, probably having the key role on those responses of the specific feature of each strain rather than colonization.

The change from pathogen to symbiotic processes are controlled by plant hormones such as strigolactone (SL) and salicylic acid (SA) in the roots [7, 19, 34, 35]. In a well-established mycorrhiza both SL and SA production are reduced while biosynthesis of jasmonates (JA) increased [23, 25, 49].

Glutathione S-transferases (GST) belong to the best known and most studied detoxification enzymes group [12]. They play a role in the inactivation of the products of the oxidative stress metabolites, which method defends the cell from the damages [44]. The glutathione S-transferases in plants not only neutralize the toxic substances, but also promote a number of defensive mechanisms in the plant's defense system against oxidative membrane damage and necrotic disease symptoms. Some of them 
can facilitate the intracellular storage and transport of hydrophobic non-substrate compounds, such as metabolites.

Similar to our results, the expression of glutathione S-transferase gene showed different gene expression under various stress situations [52] and the age of the plants had influence on it. In the present study, GST gene expression and GST enzyme activity showed the same tendency under high temperature stresses, supporting the results of Cetinkaya et al. [8]. In addition there are many post-transcriptional as well as post translational events that are involved in the processing of defense system which may explain the discrepancy of results between enzymes and transcripts under low temperature and wounding stresses.

Low temperature caused significant increase only in PPO activity compared to control plants, mycorrhizal inoculation had not any effect on it. Our result proves that often found AMF-induced enhanced chilling tolerance of plants may be attributed not only to enhanced antioxidant enzyme activity, but also to increased osmolyte accumulation, reduced lipid peroxidation and permeability in the plasma membrane, photosynthesis and secondary metabolism $[6,9,22,55]$. Moreover higher leaf water potential [14] increased calcium precipitates in the apoplast and vacuole of root cells are described [24] compared with the non AMF control.

\section{CONCLUSION}

Our results suggest that induced resistance of mycorrhizal sunflower to high temperature may be due to the induction of GST, POX and PPO enzyme activities as well as to the elevated expression of GST. However, the degree of tolerance of the plant is significantly influenced by the age which is probably justified by the energy considerations.

\section{ACKNOWLEDGEMENT}

This work was supported by Kutató Kari Kiválósági Támogatás - Research Centre of Excellence - 98783/2016/FEKUT.

\section{REFERENCES}

1. Azcón-Aguilar, C., Barea, J. M. (1997) Arbuscular mycorrhizas and biological control of soil-borne plant pathogens - an overview of the mechanisms involved. Mycorrhiza 6, 457-464.

2. Baslam, M., Goicoechea, N. (2012) Water deficit improved the capacity of arbuscular mycorrhizal fungi (AMF) for inducing the accumulation of antioxidant compounds in lettuce leaves. Mycorrhiza 22, 347-359.

3. Bonfante-Fasolo, P. (1988) The role of the cell wall as a signal in mycorrhizal associations. In: Scannerini, S., Smith, D., Bonfante-Fasolo, P., Gianinnazzi, V. (eds) Cell to cell signals in plant, animal and microbial symbiosis. Springer Berlin Heidelberg, pp. 219-235.

4. Bowles, T. M., Barrios-Masias, F. H., Carlisle, E. A., Cavagnaro, T. R., Jackson, L. E. (2016) Effects of arbuscular mycorrhizae on tomato yield, nutrient uptake,water relations, and soil carbon dynamics under deficit irrigation in field conditions. Sci. Total Environ. 566-567, 1223-1234. 
5. Bradford, M. (1976) A rapid and sensitive method for the quantitation of microgram quantities of protein utilizing the principle of protein-dye binding. Anal. Biochem. 72, 248-254.

6. Bunn, R., Lekberg, Y., Zabinski, C. (2009) Arbuscular mycorrhizal fungi ameliorate temperature stress in thermophilic plants. Ecology 90, 1378-1388.

7. Cameron, D. D., Neal, A. L., van Wees, S. C. M., Ton, J. (2013) Mycorrhiza-induced resistance: more than the sum of its parts? Trends Plant Sci. 18, 539-545.

8. Cetinkaya, H., Tasci, E., Dinler, B. S. (2014) Regulation of glutathione S-transferase enzyme activity with salt pre-treatment under heat stress in maize leaves. Res. Plant Biol. 4, 5.

9. Chen, S., Jin, W., Liu, A., Zhang, S., Liu, D., Wang, F., Lin, X., He, C. (2013) Arbuscular mycorrhizal fungi (AMF) increase growth and secondary metabolism in cucumber subjected to low temperature stress. Sci. Horticult. 160, 222-229.

10. Cordier, C., Pozo, M. J., Barea, J. M., Gianinazzi, S., Gianinazzi, Pearson V. (1998) Cell defence responses associated with localized and systemic resistance to Phytophthora induced in tomato by an arbuscular mycorrhizal fungus. Mol. Plant Microbe Interact. 11, 1017-1028.

11. Dehghan, G., Amjad, L., Nosrati, H. (2013) Enzymatic and non-enzymatic antioxidant responses of alfalfa leaves and roots under different salinity levels. Acta Biol. Hung. 64, 207-217.

12. Edwards, E., Dixon, P. D., Walbot V. (2000) Plant glutathione S-transferases: enzymes with multiple functions in sickness and in health. Trends Plant Sci. 5, 193-198.

13. Elstner, E. F. (1982) Oxygen activation and oxygen-toxicity. Ann. Rev. Plant Physiol. Plant Mol. Biol. $33,73-96$.

14. El-Tohamy, W., Schnitzler, W. H., El-Behairy, U., El-Beltagy, M. S. (1999) Effect of VA mycorrhiza on improving drought and chilling tolerance of bean plants (Phaseolus vulgaris L.). Angewandte Botanik 73, 178-183.

15. Ergün, N., Özçubukçu, S., Kolukirik, M., Temizkan, Ö. (2014) Effects of temperature-heavy metal interactions, antioxidant enzyme activity and gene expression in wheat (Triticum aestivum L.) seedlings. Acta Biol. Hung. 65, 439-450.

16. Fehrmann, H., Dimond, A. E. (1967) Peroxidase activity and phytophthora resistance in different organs of the potato plant. Phytopathology 57, 69-72.

17. Giovannetti, M., Mosse, B. (1980) An evaluation of techniques for measuring vesicular arbuscular mycorrhizal infection in roots. New Phytologist 84, 489-500.

18. Habig, W., Pabst, M. J., Jakoby, W. B. (1974) The first enzymatic step in mercapturic acid formation. Glutathione-S-transferase. J. Biol. Chem. 249, 7130-7139.

19. Jung, S. C., Martinez-Medina, A., Lopez-Raez, J. A., Pozo, M. J. (2012) Mycorrhiza-induced resistance and priming of plant defenses. J. Chem. Ecol. 38, 651-664.

20. Kohler, J., Hernández, J. A., Caravaca, F., Roldán, A. (2009) Induction of antioxidant enzymes is involved in the greater effectiveness of a PGPR versus AM fungi with respect to increasing the tolerance of lettuce to severe salt stress. Environ. Exp. Bot. 65, 245-252.

21. Lambais, M. R., Ríos-Ruiz, W. F., Andrade, R. M. (2003) Antioxidant responses in bean (Phaseolus vulgaris) roots colonized by arbuscular mycorrhizal fungi. New Phytologist 160, 421-428.

22. Latef, A. A. H. A., Chaoxing, H. (2011) Arbuscular mycorrhizal influence on growth, photosynthetic pigments, osmotic adjustment and oxidative stress in tomato plants subjected to low temperature stress. Acta Physiol. Plant. 33, 1217-1225.

23. Lendzemo, V. W., Kuyper, T. W., Matusova, R., Bouwmeester, H. J., Ast, A. V. (2007) Colonization by arbuscular mycorrhizal fungi of sorghum leads to reduced germination and subsequent attachment and emergence of Striga hermonthica. Plant Signal. Behavior 2, 58-62.

24. Liu, X., Mao, K., Angela, Y. H., Omairi-Nasser, A., Austin, J., Glick, B. S., Klionsky, D. J. (2016) The Atg17-Atg31-Atg29 complex coordinates with Atg11 to recruit the Vam7 SNARE and mediate autophagosome-vacuole fusion. Current Biol. 26, 150-160.

25. López-Ráez, J. A., Charnikhova, T., Fernández, I., Bouwmeester, H., Pozo, M. J. (2011) Arbuscular mycorrhizal symbiosis decreases strigolactone production in tomato. J. Plant physiol. 168, 294-297. 
26. Matsumura, A., Horii, S., Ishii, T. (2007) Effects of arbuscular mycorrhizal fungi and intercropping with bahiagrass on growth and anti-oxidative enzyme activity of radish. J. Jap. Soc. Horticult. Sci. $76,224-229$.

27. Mayer, A. M. (2006) Polyphenol oxidases in plants and fungi: Going places? A review. Phytochem. 67, 2318-2331.

28. Mittler, R. (2002) Oxidative stress, antioxidants and stress tolerance. Trends Plant Sci. 7, 405-410.

29. Ordoñez, N. M., Marondedze, C., Thomas, L., Pasqualini, S., Shabala, L., Shabala, S., Gehring, C. (2014) Cyclic mononucleotides modulate potassium and calcium flux responses to $\mathrm{H} 2 \mathrm{O} 2$ in Arabidopsis roots. FEBS letters, 588, 1008-1015.

30. Passardi, F., Penel, C., Dunand, C. (2004) Performing the paradoxical: how plant peroxidases modify the cell wall. Trends Plant Sci. 9, 534-540.

31. Paszkowski, U. (2006) Mutualism and parasitism: the yin and yang of plant symbioses. Curr. Op Plant Biol. 9, 364-370.

32. Pérez, E., Rodríguez, Y., Hernández, M. A., de la Noval y B. M. (2004) Dinámica de inducción de algunos sistemas de defensa en la interacción HMA-tomate (Lycopersicon esculentum Mill.) var. Amalia. II. Inducción y expresión de peroxidasas y polifenoloxidasas en raíces de tomate. Cultivos Tropicales 25, 45-52.

33. Pfeiffer, T., Štolfa, I., Žanić, M., Pavičić, N., Cesar, V., Lepeduš, H. (2013) Oxidative stress in leaves of two olive cultivars under freezing conditions. Acta Biol. Hung. 64, 341-351.

34. Pozo, M. J., López-Ráez, J. A., Azcón-Aguilar, C., García-Garrido, J. M. (2015) Phytohormones as integrators of environmental signals in the regulation of mycorrhizal symbioses. New Phytol. 205, $1431-1436$.

35. Pozo, M. J., Azcón-Aguilar, C. (2007) Unravelling mycorrhiza-induced resistance. Curr. Op. Plant Biol. 10, 393-398.

36. Pozo, M. J., Cordier, C., Dumas-Gaudot, E. (2002) Localized versus systemic effect of arbuscular mycorrhizal fungi on defence responses to Phytophthora infection in tomato plants. J. Exp. Bot. 53, $525-534$

37. Radwan, O., Mouzeyar, S., Venisse, J. S., Nicolas, P., Bouzidi, M. F. (2005) Resistance of sunflower to the biotrophic oomycete Plasmopara halstedii is associated with a delayed hypersensitive response within the hypocotyls. J. Exp. Bot. 56, 1683-2693.

38. Rahmaty, R., Khara, J. (2011) Effects of vesicular arbuscular mycorrhiza Glomus intraradices on photosynthetic pigments, antioxidant enzymes, lipid peroxidation, and chromium accumulation in maize plants treated with chromium. Turkish J. Biol. 35, 51-58.

39. Rathmell, W. G., Sequeira, L. (1974) Soluble peroxidase in fluid from the intercellular spaces of tobacco leaves. Plant Physiol. 53, 317-318.

40. Rodríguez, Y., Vierheilig, H., Mazorra, L. M. (2012) Alterations of the Antioxidant Enzyme Activities are not General Characteristics of the Colonization Process by Arbuscular Mycorrhizal Fungi. Chilean J. Agric. Res. 72, 411-418.

41. Scervino, J. M., Gottlieb, A., Silvani, V. A., Pérgola, M., Fernández, L., Godeas, A. M. (2009) Exudates of dark septate endophyte (DSE) modulate the development of the arbuscular mycorrhizal fungus (AMF) Gigaspora rosea. Soil Biol. Biochem. 41, 1753-1756.

42. Scervino, J. M., Ponce, M. A., Erra-Bassells, R., Vierheilig, H., Ocampo, J. A., Godeas, A. (2005) Flavonoids exhibit fungal species and genus specific effects on the presymbiotic growth of Gigaspora and Glomus. Mycol. Res. 109, 789-794.

43. Scervino, J. M., Ponce, M. A., Erra-Bassells, R., Bornpadre, J., Vierheilig, H., Ocampo, J. A., Godeas, A. (2007) The effect of flavones and flavonols on colonization of tomato plants by arbuscular mycorrhizal fungi of the genera Gigaspora and Glomus. Can. J. Microbiol. 53, 702-709.

44. Sharma, R., Yang, Y., Sharma, A., Awasthi, S., Awasthi, Y. C. (2004) Antioxidant role of glutathione S-transferases: protection against oxidant toxicity and regulation of stress-mediated apoptosis. Antioxid. Redox Signal. 6, 289-300.

45. Smith, S. E., Jakobsen, I., Grønlund, M., Smith, F. A. (2011) Roles of arbuscular mycorrhizas in plant phosphorus nutrition: interactions between pathways of phosphorus uptake in arbuscular mycorrhizal 
roots have important implications for understanding and manipulating plant phosphorus acquisition. Plant Physiol. 156, 1050-1057.

46. Smith, S. E., Read, D. J. (1997) Mycorrhizal Symbiosis, 2nd ed. Academic Press, London.

47. Smith, S. E., Read, D. J. (2008) Mycorrhizal Symbiosis, 3rd ed. Academic Press, London.

48. Smith, S. E., Smith, F. A. (2011) Roles of arbuscular mycorrhizas in plant nutrition and growth: new paradigms from cellular to ecosystems scales. Annu. Rev. Plant Biol. 63, 227-250.

49. Steinkellner, S., Lendzemo, V., Langer, I., Schweiger, P., Khaosaad, T., Toussaint, J. P., Vierheilig, H. (2007) Flavonoids and strigolactones in root exudates as signals in symbiotic and pathogenic plantfungus interactions. Molecules 12, 1290-1306.

50. Taylor, T. N., Remy, W., Hass, H., Kerp, H. (1995) Fossil arbuscular mycorrhizae from the Early Devonian. Mycologia 87, 560-573.

51. Vierheilig, H., Coughlan, A. P., Wyss, U., Piché, Y. (1998) Ink and vinegar, a simple staining technique for arbuscular-mycorrhizal fungi. Appl. Environ. Microbiol. 64, 5004-5007.

52. Wagner, U., Edwards, R., Dixon, D. P., Mauch, F. (2002) Probing the diversity of the Arabidopsis glutathione S-transferase gene family. Plant Mol. Biol. 49, 515-532.

53. Wu, Q. S., Zou, Y. N. (2009) Mycorrhiza has a direct effect on reactive oxygen metabolism of drought-stressed citrus. Plant Soil Environ. 55, 436-442.

54. Xin, Z., Browse, J. (2000) Cold comfort farm: the acclimation of plants to freezing temperatures. Plant, Cell \& Environ. 23, 893-902.

55. Zhu, J., Ha Lee B., Dellinger M., Cui X., Zhang C., Wu S., Nothnagel E.A., Zhu J.K. (2010) A cellulose synthase-like protein is required for osmotic stress tolerance in Arabidopsis. Plant J. 63, $128-140$. 